\title{
Endotoxin-induced Abortion in Early Pregnant Gilts and its Prevention by Flunixin Meglumine
}

\author{
By Nicholas Cort and Hans Kindahl
}

Department of Obstetrics and Gynaecology, College of Veterinary Medicine, Swedish University of Agricultural Sciences, Uppsala, Sweden.

\begin{abstract}
Cort, N. and H. Kindahl: Endotoxin-induced abortion in early pregnant gilts and its prevention by flunixin meglumine. Acta vet. scand. 1990, 31, 347-358. - The objective of the study was to examine the effect of endotoxin on early pregnancy in gilts and to test the potential of flunixin meglumine (FM), a cyclooxygenase inhibitor, to counteract abortifacient action of the endotoxin. Ten gilts at $\mathbf{3 0}$ days gestation were used in the experiment. Eight were injected with lipopolysaccharide (LPS) of Salmonella typhimurium, while 2 were treated with $500 \mu \mathrm{g}$ cloprostenol (CP). Six of the LPS-injected gilts were treated with a total of $4 \mathrm{mg} / \mathrm{kg}$ body weight FM in 2 different dose regimens. Clinical observations were recorded and plasma levels of 15 -keto-13, 14-dihydro-PGF ${ }_{2 a}$, progesterone and estrone sulfate (ES) were determined with radioimmunoassay.

LPS induced typical signs of endotoxemia and a monophasic fever in all LPStreated gilts. No antipyretic effect of FM was observed. The CP-treated gilts aborted within $34 \mathrm{~h}$ as did the gilts treated by LPS only. Of the 6 LPS + FM-treated gilts, 1 aborted within $34 \mathrm{~h}$, while 5 maintained gestation. These were aborted about a week later by $\mathrm{CP}$ and the aborted fetuses anatomically examined. Two of the litters were lost (devoured by the dams), 2 showed no signs of earlier death and 1 showed extensive fetal death.

The $\mathrm{PGF}_{2 a}$ metabolite concentrations increased at least 10 fold immediately after the LPS injection. Progesterone plasma concentration decreased rapidly. A 5-10 fold increase in the plasma metabolite levels accompanied all abortions. CP caused no immediate change in the PGF $_{2 a}$ metabolite levels, but the abortion-related response was similar to that in LPS-injected gilts. In the FM-treated gilts, the LPSinduced $\mathrm{PGF}_{2 a}$ metabolite response was rudimentary and the progesterone decrease temporary in nonaborting gilts. The elevated concentrations of ES decreased within $\mathbf{4 8} \mathrm{h}$ in gilts aborting at 30 days gestation, while in nonaborting gilts a slow, graduate decrease of ES occurred within 3-5 days of the LPS injection. These results indicate that FM apparently suppressed LPS-induced prostaglandin synthesis and thus prevented luteolysis and abortion in early pregnant gilts.
\end{abstract}

\section{Introduction}

Endotoxins of Gram-negative bacteria administered to pregnant animals cause abortion and fetal death. Two major mechanisms are thought to be responsible for the gestation failure: Disseminated intravascular coagulation and endothelial damage causing malfunction of the placenta and fetal death
(Rieder \& Thomas 1960, Dennis 1966, Culbertson \& Osburn 1980) and the endotoxininduced synthesis of endogenous prostaglandins (PG), among which $\mathrm{PGF}_{2 \alpha}$ may cause premature regression of the corpus luteum (c.l.) and abortion (Roberts et al. 1975). Abortion induced by endotoxin in 60-80 days pregnant sows (Wrathall et al. 1978, 
Cort et al. 1986) showed similar course and hormonal pattern as abortion induced by PGF $_{2 a}$ or CP (Wrathall et al. 1978, Cort et al. 1986, Podany et al. 1982). These findings support the theory that the luteolytic effect of endotoxin was the principal abortifacient factor (Cort et al. 1986). In contrast, abortion was not induced by endotoxins in 80100 days pregnant sows, indicating increased resistance to abortifacient factors in late gestation in the pig (Cort \& Kindahl 1986).

Early gestation in the pig, as in other animal species, is generally more sensitive to damage than mid to late gestation. The embryonic phase is characterized by a dramatic growth and development of tissues and organs and rapid development of the placenta. Vulnerability to infectious diseases is high, as the conceptus is not immunologically competent until 60-70 days of prenatal age (Wang et al. 1973, Wrathall 1980). Therefore early gestation in the pig would have been expected to be at least as sensitive to endotoxin as mid gestation. However, what the embryonic phase has in common with the period from 80 days to term is increased plasma concentrations of estrone sulfate, synthetised by the conceptus (Robertson \& King 1974). A number of studies on the early gestation in the pig indicated that estrogens have an antiluteolytic/luteotropic function (Bazer \& First 1983).

Harper \& Skarnes (1972) in studies involved in preventing the abortifacient effect of endotoxins found that 1 ) injection of $\mathrm{PGF}_{2 a}$ produced the same extent of abortion or intrauterine fetal death in mice as endotoxin; 2) progesterone or indomethacin prevented endotoxin-induced abortion, but not fetal death, 3) indomethacin plus cyproheptadine (serotonin inhibitor) treatment prevented both abortion and fetal death in endotoxininjected mice. These results implicate PGs being involved in both luteolytic and fetopathic effect of endotoxin.

Luteolysis and expulsion of fetuses in sows occur within $40 \mathrm{~h}$ of endotoxin injection, which does not allow a possible primary fetopathic effect of endotoxin to be distinguished from the secondary fetal damage caused by the process of expulsion (Wrathall et al. 1978, Cort et al. 1986). Removing of the PG involvement in the mechanism of initiation of abortion may bring some light upon the actual role of PGs in the pathogenic effect on gestation.

Flunixin meglumine (FM) is a non-steroidal antiinflammatory drug, which has been used for the past 10 years mainly in horses with colic of musculoskeletal disorders (Houdeshell \& Hennessey 1977, Vernimb \& Hennessey 1977). FM was found to effectively counteract experimental endotoxemia in horses and dogs (Bottoms et al. 1981, Turek et al. 1985, Hardie et al 1987). The antiinflammatory effect is based on potent cyclooxygenase inhibition, preventing metabolism of arachidonic acid to vasoactive PGs and thromboxanes (Moore et al. 1986).

The aims of the present study were to i) investigate the effect of bacterial endotoxin on early pregnancy in gilts by means of clinical observations and analysis of blood progesterone, estrone sulfate and plasma metabolite of $\mathrm{PGF}_{2 \alpha}, 15$-keto-13, 14-dihydro-PGF ${ }_{2 a}$, ii) to compare these results to the earlier obtained ones in mid/late gestation and iii) to investigate the effect of FM on the synthesis and release of $\mathrm{PGF}_{2 \alpha}$ and the possibility of preventing endotoxin-induced abortion or fetal death by treatment with FM.

\section{Material and methods}

Ten sexually mature Hampshire $x$ Landrace $x$ Yorkshire gilts were purchased from a commercial herd, housed individually and 
fed a standard ration. After observation of at least 1 normal estrous cycle the gilts were inseminated or mated by a boar. Pregnancy was confirmed by a Doppler instrument (Medata System Ltd., Yapton, England) at 25 days after service. Jugular vein catheters were inserted surgically under general anesthesia, 5-3 days prior to the experiment ( $R O$ driguez-Martinez \& Kunavongkrit 1983). At 30 days of gestation $( \pm 2), 2$ gilts were injected i.m. with $500 \mu \mathrm{g}$ cloprostenol (CP) and 8 gilts were injected i.v. with $2 \mu \mathrm{g} / \mathrm{kg}$ body weight (b.w.) lipopolysaccharide (LPS) of Salmonella typhimurium SH (4809) (Svensson \& Lindberg 1978, Lindberg et al. 1983). Six of the LPS-treated gilts were injected i.v. with $2 \mathrm{mg} / \mathrm{kg}$ b.w. flunixin meglumine (FM) (Finadyne, Schering Corp., Kenilworth, N.J., USA), $12 \mathrm{~h}$ prior to the LPS injection. Further treatment by FM was performed in a relationship to the LPS injection as follows: 2 gilts, $2 \mathrm{mg} / \mathrm{kg}$ b.w. at -2 and $+10 \mathrm{~h}, 4$ gilts, $1 \mathrm{mg} / \mathrm{kg} \mathrm{b} . \mathrm{w}$. at $-2,+2,+6$ and $+10 \mathrm{~h}$.

Clinical observations were made and rectal temperature periodically taken in all animals. Bloọd samples for hormone analysis were collected at intervals varying between 1 and $12 \mathrm{~h}$. The blood was immediately centrifuged and plasma stored at $-20^{\circ} \mathrm{C}$. Gilts which did not abort due to the LPS injection were treated within 5 to 8 days with CP, 500 $\mu \mathrm{g}$ i.m. The aborted fetuses and fetal membranes were anatomically examined.

The experimental animals were further observed through the first estrus post abortum. Uteri and ovaries in aborting gilts were examined by laparoscopy and/or at slaughter. The plasma levels of progesterone (Bosu et al. 1976), 15-keto-13, 14-dihydro- PGF $_{2 \alpha}$ (15ketodihydro- $\mathrm{PGF}_{2 a}$ ) (Kindahl et al. 1976) and estrone sulfate (ES) (Wright et al. 1978) were analysed by radioimmunoassay. These assays have been earlier validated for porcine species (Cort et al. 1986).
Student's t-test was used for analysis of difference between the pairs of mean temperatures of LPS + FM-treated gilts in the present study and LPS-treated gilts from a recent clinical study, which was performed under the same conditions (Cort 1986).

\section{Results}

The clinical response to LPS injections at $\mathbf{3 0}$ days of gestation were arbitrarily characterized by a scale from no response (-) to severe signs $(+++)$ of endotoxemia (Table 1). These included various degrees of fever, vomiting, circulatory shock, dyspnea, ataxia and anorexia. LPS injections were followed by a severe clinical syndrome, while no clinical response was observed after $\mathrm{CP}$ injections. All the typical signs of the syndrome were present i LPS + FM-treated gilts although none showed as severe clinical endotoxemia as the LPS-treated ones. The duration of the clinical signs was between 1 and 8 $h$ after injection (a.i.). Anorexia usually persisted until next day. Yellow discoloration of the plasma was observed between 3 and 12 a.i. in both LPS-treated and LPS + FM-treated animals.

Rectal temperature remained within physiological range in CP- injected gilts. The LPS + FM-treated gilts demonstrated a monophasic fever curve beginning with a sharp rise immediately after the LPS injection and maintaining above $40^{\circ} \mathrm{C}$ for $2-5 \mathrm{~h}$ a.i.; a gradual decrease occurred towards the end of the $12 \mathrm{~h}$ monitoring period (Fig. 1A). LPStreated gilts (nos. 3 and 4) showed nearly identical temperature curves as those of the LPS + FM group (date not shown). Similar temperature response has been obtained from LPS-treated gilts in a recent clinical study (Fig. 1B). The mean values $(n=8)$ from the temperature curve in the recent clinical study were chronologically compared to those of the LPS + FM-treated group 
Table 1. Clinical data on pregnant gilts injected by cloprostenol (CP) or endotoxin (LPS) at 30 days of pregnancy.

\begin{tabular}{|c|c|c|c|c|c|c|c|c|c|}
\hline $\begin{array}{l}\text { Gilt } \\
\text { no. }\end{array}$ & $\begin{array}{l}\text { Injection } \\
\text { day } 30\end{array}$ & $\begin{array}{l}\text { Clinical } \\
\text { response }\end{array}$ & Abortion & $\begin{array}{c}\text { CP } \\
\text { days after } \\
\text { 1st inj. }\end{array}$ & $\begin{array}{l}\quad \text { Inte } \\
\text { injection } \\
\text { /abortion }\end{array}$ & $\begin{array}{l}\text { rval } \\
\text { abortion } \\
\text { /estrus }\end{array}$ & $\begin{array}{c}\text { Fetuses } \\
\text { total/ } \\
\text { autolytic }\end{array}$ & $\begin{array}{l}\text { Ovar } \\
\text { a.a. } \\
\text { day }\end{array}$ & $\begin{array}{l}\text { rian condition } \\
\text { observation }\end{array}$ \\
\hline 1 & $\mathrm{CP}$ & - & yes & $\ldots$ & 34 & 4 & $14 / 0$ & 10 & $14 \mathrm{c.l}$ \\
\hline 2 & CP & - & yes & $\ldots$ & 30 & 4 & $8 / 0$ & 12 & $17 \mathrm{c.l}$ \\
\hline 3 & LPS & +++ & yes & $\ldots$ & 28 & 8 & $15 / 0$ & 30 & $9 \mathrm{c.l}$ \\
\hline \multirow[t]{2}{*}{4} & LPS & +++ & yes & $\ldots$ & 40 & 4 & $13 / 10$ & 5 & 15 follicles \\
\hline & $\begin{array}{l}\text { LPS } \\
\text { FM } \mathrm{mg} / \mathrm{kg}\end{array}$ & & & & & & & & \\
\hline 5 & $2 \times 2$ & $++t$ & yes & & 34 & 8 & $7 / 0$ & 24 & $12 \mathrm{c} .1$ \\
\hline 6 & $2 \times 2$ & ++ & no & 7 & 41 & 7 & $\begin{array}{c}\text { all } \\
\text { devoured }\end{array}$ & 14 & $15 \mathrm{c.l}$ \\
\hline 7 & $4 \times 1$ & ++ & no & 8 & 40 & 5 & $9 / 0$ & 34 & $14 \mathrm{c} .1$ \\
\hline 8 & $4 \times 1$ & ++ & no & 6 & 41 & 5 & $8 / 0$ & 17 & 17 c.l \\
\hline 9 & $4 \times 1$ & ++ & no & 7 & 38 & 4 & $13 / 9$ & 33 & $18 \mathrm{c} .1$ \\
\hline 10 & $4 \times 1$ & + & no & 5 & 30 & 5 & $\begin{array}{c}\text { all } \\
\text { devoured }\end{array}$ & 35 & 22 c.l \\
\hline
\end{tabular}

*Gilts nos. 5 to 10 were treated by flunixin meglumine (FM) in schedule $2 \times 2$ or $4 \times 1 \mathrm{mg} / \mathrm{kg}$ body weight during treatment by LPS

c.l. $=$ corpora lutea; $\mathbf{a} . \mathbf{a} .=$ after abortion

$(n=6)$ (Fig. 1A). The mean of the LPS + FM group was significantly higher $(p<0.05)$ at 0 $\mathrm{h}$ and significantly lower $(\mathrm{p}<0.01)$ at $1 \mathrm{~h}$ a.i. than the respective mean of the LPS group.
The rest of the pairs of values between -2 and $12 \mathrm{~h}$ a.i. were not significantly different. The effect of the experiment on gestation is summarized in Table 1. All CP-treated ani-

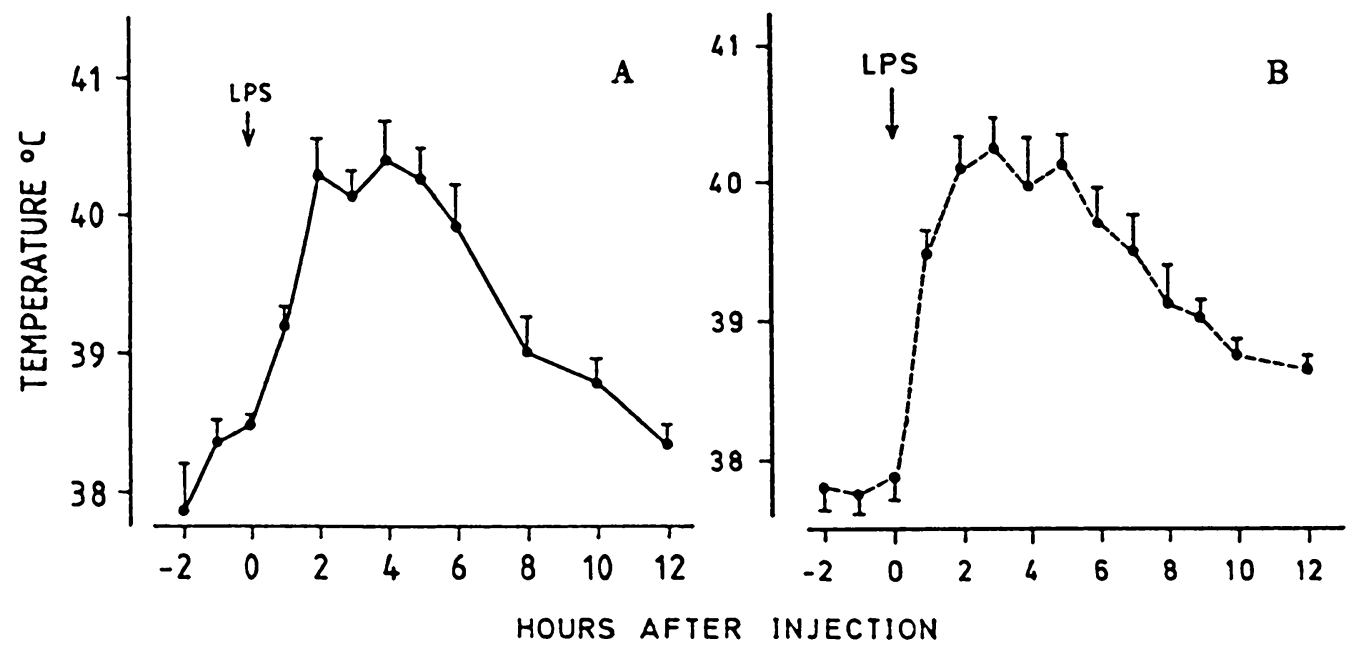

Figure 1. The mean \pm SE of body temperature in gilts treated with LPS and FM in the present study (A) and gilts treated with LPS in our recent clinical study (B) (Cort 1986). 
mals (nos. 1 and 2 at 30 days, nos. 6-10 reinjected) aborted within $48 \mathrm{~h}$. LPS caused abortions in gilts nos. 3-5, while nos. 6-10 maintained pregnancy. The maintenance of pregnancy was repeatedly verified by the Doppler instrument. The interval between abortifacient injection and the onset of the fetal expulsion ranged between 28 and $41 \mathrm{~h}$. The duration of the abortions was 6 to $12 \mathrm{~h}$. Anatomical examination of the aborted fetuses plus membranes indicated that fetal death occurred at abortion in all gilts except no. 9; while the condition of the fetuses were impossible to assess in gilts nos. 6 and 10 as all the fetuses were immediately devoured by the aborting animals. Size of the fetuses corresponded to the stage of gestation. Some hemorrhage into the amnionic fluid and mild congestion of tissues was observed in fetuses from gilts nos. 1, 4 and 8 , but none of the fetuses had signs of advanced autolysis. However 9 of 13 fetuses in gilt no. 9 appeared smaller in size than expected and showed signs of advanced autolysis, maceration of soft tissues and necrosis of the placental membranes. These fetuses were particularly traumatized during the delivery.

Gilts showed signs of estrus 4-8 days after abortion (a.a.) (Table 1). The duration of this estrus was 1 to 3 days. The gilts were examined by laparoscopy or slaughtered during the first or second estrous cycle a.a.. No uterine abnormalities were noted.

Fig. 2 shows an example of a hormonal pattern of an induced abortion at 30 days gestation in the pig. The 15 -ketodihydro- PGF $_{2 a}$ maintained concentrations between 0.2 and $1 \mathrm{nmol} / \mathrm{l}$ towards day 30 (base levels). The

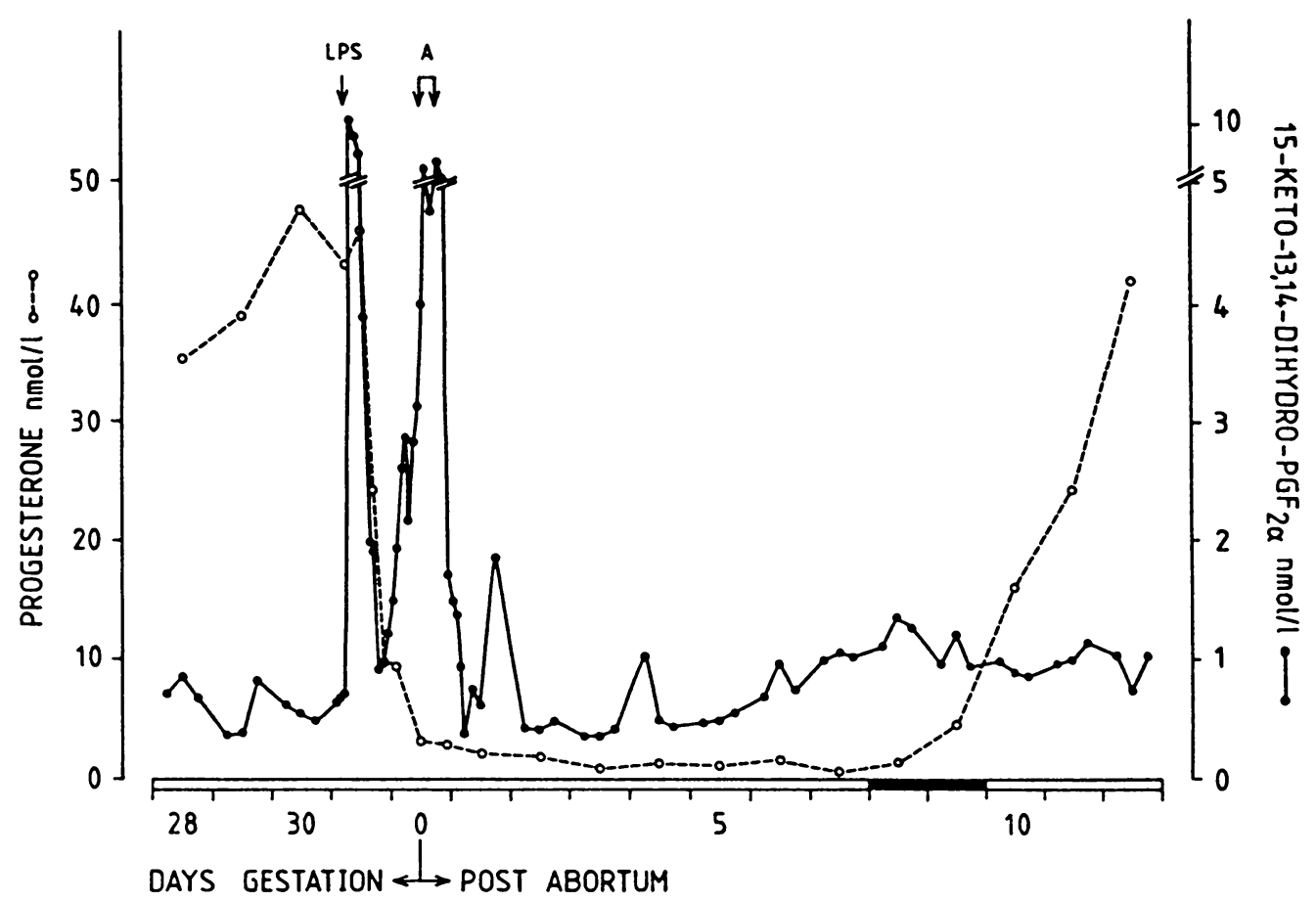

Figure 2. Plasma levels of progesterone and 15-keto-13, 14-dihydro- PGF $_{2 a}$ before and after abortion (A) induced by endotoxin (LPS) in gilt no. 3 at 30 days gestation. The horizontal thick bar marks estrus. 
LPS injection was immediately followed by a dramatic surge to peaks above $10 \mathrm{nmol} / \mathrm{l}$. Thereafter the concentrations gradually decreased and reached base levels within $8 \mathrm{~h}$ a.i.. A second massive increase in plasma concentrations of the $\mathrm{PGF}_{2 \alpha}$ metabolite began within 8-12 $\mathrm{h}$ a.i., reaching peak values of 5-10 $\mathrm{nmol} / \mathrm{l}$ within $30-38 \mathrm{~h}$ a.i.. Expulsion of the fetuses occurred in conjunction with the second peak. The $\mathrm{PGF}_{2 a}$ metabolite concentrations returned to base levels between
48 and $80 \mathrm{~h}$ a.i. with occasional surges being observed during the first day a.a.. CP injections did not cause any immediate change in the base levels of 15-ketodihydro-PGF ${ }_{2 \alpha}$. A massive increase in $\mathrm{PGF}_{2 a}$ metabolite concentration began at 8-10 $\mathrm{h}$ a.i. and reached peak values of 3-8 $\mathrm{nmol} / 1$ at $28-40 \mathrm{~h}$ a.i. at which time the expulsion of the fetuses occurred. The pattern of progesterone plasma levels was identical for LPS and CP administrations. The hormone maintained levels

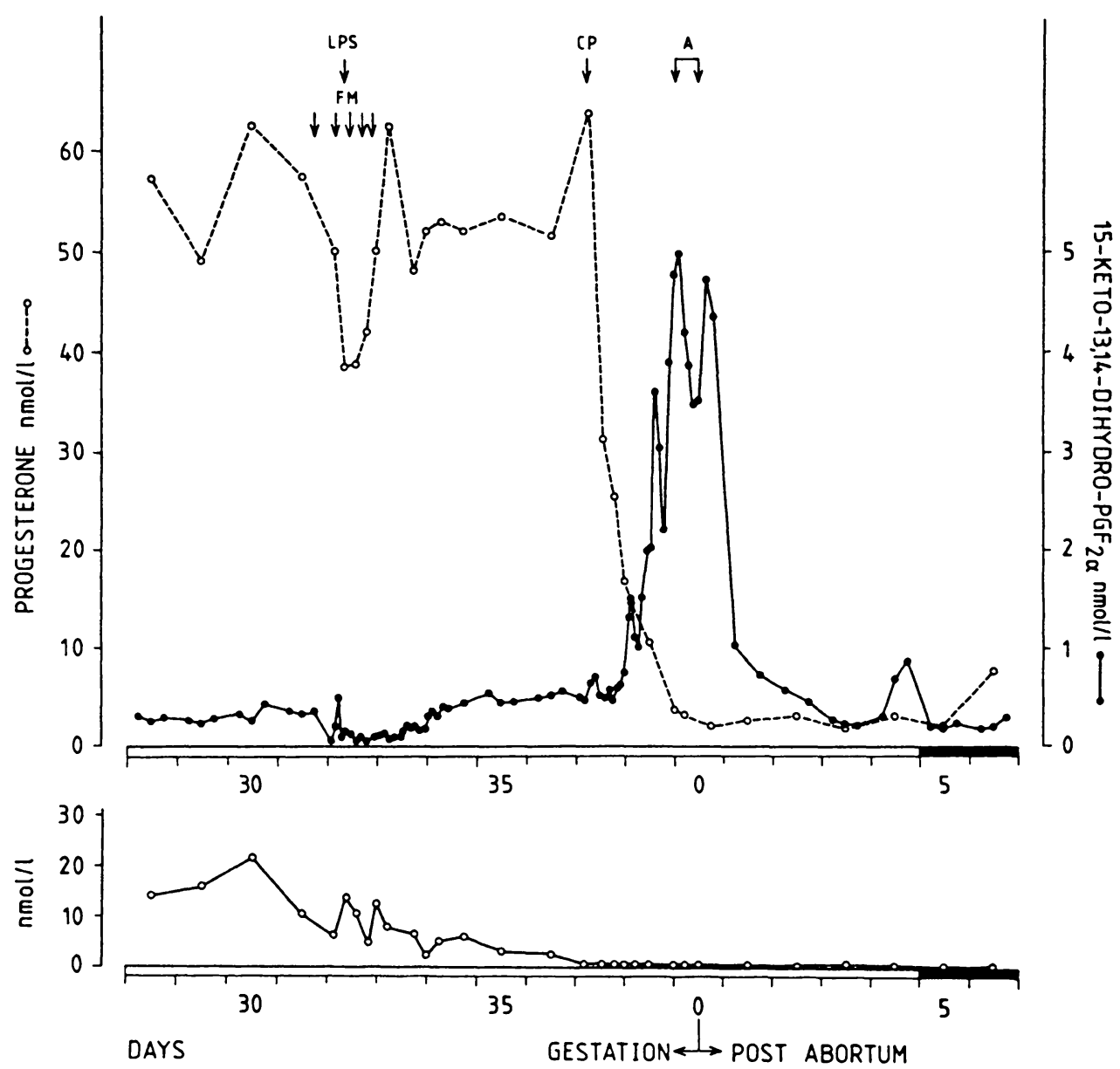

Figure 3. Plasma levels of progesterone, 15-keto-13, 14-dihydro-PGF ${ }_{2 a}$ and estrone sulfate during treatment with endotoxin (LPS) plus flunixin meglumine (FM) in gilt no. 10 at 30 days gestation. Injection of cloprostenol (CP) 5 days later induced abortion (A). The horizontal thick bar marks estrus. 
above $30 \mathrm{nmol} / 1$ towards day 30 of gestation. Injection of LPS and CP were followed by a decrease in progesterone concentrations to less than $5 \mathrm{nmol} / \mathrm{l}$ within $25 \mathrm{~h}$. Progesterone values remained low until after the first estrus when a gradual rise confirmed that ovulation had occurred.

In the LPS + FM group pretreatment by FM decreased the base levels of 15-ketodihydro$\mathrm{PGF}_{2 \mathrm{a}}$ to values as low as $20 \mathrm{pmol} / \mathrm{l}$ (Fig. 3). The LPS injection during repeated treatment by FM was followed by a surge of the PGF metabolite. This surge was reduced in maximum values $(0.5-2.1 \mathrm{nmol} / \mathrm{l})$ in comparison to that in LPS-treated gilts. The highest 15 -ketodihydro- $\mathrm{PGF}_{2 \alpha}$ peak values were observed in gilt no. $5(2.1 \mathrm{nmol} / \mathrm{l})$ and no. 6 (1.6 nmol/l) both of which received $2 \times 2$ $\mathrm{mg} / \mathrm{kg}$ FM treatment. The abortion in gilt no. 5 was accompanied by a strong increase in the $\mathrm{PGF}_{2 \mathrm{a}}$ metabolite concentration, reaching a peak of $4 \mathrm{nmol} / \mathrm{l}$ at $30 \mathrm{~h}$ a.i. No abortion occurred in the rest of the LPS + FM group. A gradual increase in the $\mathrm{PGF}_{2 \alpha}$ metabolite concentration began at 2-4 $\mathrm{h}$ after the last FM injection. The concentrations reached pretreatment values at 25-30 h after the last dose of FM (Fig. 3). The CP injections 5-8 days later produced the same hormonal pattern as in gilts no. 1 and 2 at 30 days of gestation. After the abortion, the $\mathrm{PGF}_{2 \alpha}$ metabolite remained on base level through the onset of first estrus.

Progesterone in the LPS + FM group maintained concentrations between 30 and 60 nmol/1 prior to 30 days gestation (Fig. 3). The LPS injection was followed by an immediate drop in progesterone plasma concentrations to $20-60 \%$ of the preinjection level. However, the decrease was only temorary returning to preinjection plasma levels within approximately 2 days and remaining on high level until the CP injection.

Plasma concentrations of estrone sulfate
(ES) in all gilts ranged between 5 and 40 nmol/1 2-3 days prior to the day of the experiment (Fig. 3). From these values ES decreased to undetectable concentrations within $48 \mathrm{~h}$ in aborting gilts and within 3-5 days in non-aborting gilts after experiment at $\mathbf{3 0}$ days.

\section{Discussion}

The clinical picture of endotoxemia described in the present study was similar to that observed previously (Wrathall et al. 1978, Cort 1986). Treatment by FM did not bring about dramatic improvement in the clinical manifestation of endotoxemia. Temperature patterns were not different between gilts treated with LPS + FM and gilts treated with LPS only (Fig. 1). Althouth temperatures were higher in the LPS + FM group compared to LPS group at $0 \mathrm{~h}$, the mean values of both groups at this time were within the normal physiological range for body temperature in the pig. A significantly lower mean temperature was observed in the LPS + FM group at $1 \mathrm{~h}$ a.i. indicating that the initial effect of endotoxin on temperature in this group was delayed. These findings do not support an antipyretic effect of FM. As prostaglandin synthesis was greatly modulated by FM, other pyrogens than prostaglandinrelated ones (Skarnes et al. 1981) were probably involved in the endotoxic fever. So far only monophasic endotoxic fever has been observed in pigs, whereas dosedependent biphasic fever was observed in ewes (Cort 1986, Skarnes et al. 1981). In the present experiment, the dose of $2 \mu \mathrm{g} / \mathrm{kg}$ LPS is a relatively high one, however both FM treatment schedules $(2 \times 2$ and $4 \times 1)$ represent twice the therapeutic dose per day recommended for pigs. Thus a noticable antipyretic effect of the FM would have been expected. The corresponding duration of fever and other clinical signs conform with previous observations (Cort 1986). 
Cloprostenol induced abortions within $34 \mathrm{~h}$ in gilts at 30 days gestation and within $41 \mathrm{~h} \mathrm{5-}$ 8 days later. The present results together with previous studies in mid gestation and late gestation show that $\mathrm{CP}$ at a dose of 500 $\mu \mathrm{g}$ i.m. was an effective abortifacient throughout gestation in the pig (Cort 1986, Cort \& Kindahl 1986). These findings conform with those of other authors (Podany et al. 1982). In our previous studies $C P$ has been used in comparison with LPS (Cort et al. 1986, Cort \& Kindahl 1986). The abortifacient effect of CP and LPS has been very similar up to day 80 of gestation including the injection-abortion interval, course of abortion and abortion-estrus interval. This supports the luteolytic role of the LPSmediated endogenous prostaglandin synthesis.

The size and anatomical condition of aborted fetuses in gilts nos. 1-5 indicated that no spontaneous death had taken place prior to day 30 . The rapid course of abortion did not allow the detection of any LPS-induced primary fetal death. In gilts nos. 6-10 which maintained gestation after LPS injection, the delay of 5-8 days to the CP-induced abortion should have revealed if LPS-induced fetal death occurred in the presence of FM treatment. An interval of approximately 1 week seemed to be adequate for macroscopic recognition of the difference between those fetuses which died of endotoxemia and those which survived - at the same time not long enough for advanced autolysis of dead fetuses. As apparent from Table 1, no fetal death took place in gilts nos. 7 and 8. Extensive fetal death occurred in no. 9. The advanced autolysis and uniform growth deficit in 9 of the fetuses indicated that death had occurred approximately 1 week prior of CP treatment, which suggests that death was LPS-induced.

Estrus was observed within 4-8 days follow- ing abortion without signs of reproductive disorders. Lack of reproductive disorders after induced abortions in early gestation was also described by Guthrie \& Polge (1978) and Podany et al. (1982), in contrast to abortion in late gestation in the pig when reproductive disorders frequently occur (Cort \& Kindahl 1986).

Plasma patterns of progesterone and 15-ketodihydro- $\mathrm{PGF}_{2 \alpha}$ accompanying $\mathrm{CP}$ and LPS-induced abortions at $\mathbf{3 0}$ days gestation were nearly identical to those at 60 days and for CP at 80-100 days (Cort et al. 1986, Cort $\&$ Kindahl 1986). However, in the present experiment the maximum concentrations of the $\mathrm{PGF}_{2 a}$ metabolite during the expulsion of the fetuses represented about $30 \%$ of the values obtained at later stages of gestation. During parturition and abortion, the contractile activity of the uterus seems to be the origin of the massive $\mathrm{PGF}_{2 a}$ outflow into the blood circulation (First \& Bosc 1979, Cort et al. 1986). As the total volume and mass of the conceptus in early gestation is a mere fragment of that in mid/late gestation, the amounts of $\mathrm{PGF}_{2 \alpha}$ released may be proportional to difference to contractile activity necessary for the expulsion of the conceptus. The effect on FM on the 15-ketodihydro$\mathrm{PGF}_{2 a}$ concentrations was dramatic. Base levels of the metabolite were barely detectable in the peripheral blood circulation immediately after pretreatment by FM. A study showing that FM did not interfere with metabolism of $\mathrm{PGF}_{2 a}$ into 15-ketodihydro-PGF was performed by Odensvik et al. (1989). Thus the decrease in prostaglandin metabolite levels is probably caused by inhibition of the cyclooxygenase activity by FM, blocking the biosynthesis of prostaglandins (Moore et al. 1986, Odensvik et al. 1989).

The purpose of pretreatment by FM in the present study was to minimize the base levels of the metabolite in order to obtain a clear 
measure of any induced release of $\mathrm{PGF}_{2 \alpha}$ at the time of the experiment. The schedule of $2 \times 2 \mathrm{mg} / \mathrm{kg}$ b.w. of FM seemed to be marginal for the prevention of abortion in gilt no. 5. Apparently, 2 high doses of FM administered $10 \mathrm{~h}$ apart could not prevent the LPS from generating luteolytic concentrations of $\mathrm{PGF}_{2 \alpha}$. A schedule of $4 \times 1 \mathrm{mg} / \mathrm{kg}$ b.w. of FM was set up in order to expose the gilts to a steady pharmacologically active blood level of FM throughout the duration of the endotoxemia. This proved to be successful, as the $\mathrm{PGF}_{2 \alpha}$ response to LPS in these gilts was rudimentary (Fig. 3) in comparison to the usual one (Fig. 2). The concomitant temporary decrease of progesterone indicated that a biologically active amount of $\mathrm{PGF}_{2 a}$ was synthesized and released in these animals in the presence of FM. It seems obvious that inhibition of the endotoxin's luteolytic effect by FM was responsible for maintenance of gestation in gilts nos. 6-10.

Plasma concentrations of ES declined rapidly in aborting animals which reflects the embryonic origin of the hormone (Robertson \& King 1974). In non-aborting gilts a gradual decrease in ES took place between days 30 and 40. This decrease occurs during normal gestation in the pig. ES concentrations remain low until 65-75 days when the concentrations gradually increase until term ( $R o$ bertson \& King 1974). The character of ES decline in nonaborting gilts was not related to whether LPS-related fetal death did (no. 9) or did not (nos. 7, 8 occur).

The dose of endotoxin $(2 \mu \mathrm{g} / \mathrm{kg} \mathrm{b}$.w.) should be considered a high one as compared to the natural dose released by Gram-negative bacteria. Thus the dose of FM recommended for therapy of acute bacterial diseases in the pig might have been effective against the concentrations of prostaglandins released in a natural infection. A large number of other prostaglandin synthesis inhibitors are clinically effective as antiinflammatory and analgesic drugs (Flower 1974). Besides flunixin meglumine, other drugs such as acetylsalicylic acid, indomethacin and phenylbutazone have been found effective in treatment of experimental endotoxemia (Fletcher et al. 1976, Burrows 1981). Harper \& Skarnes (1972) have successfully used indomethacin to inhibit endotoxin-induced abortion in mice. Knowledge of the course of endotoxemia in infected pregnant animals is thus imperative for adopting an appropriate model of treatment by antiinflammatory drugs based on prostaglandin synthesis inhibition to preserve gestation.

FM treatment in the present study inhibited LPS-induced $\mathrm{PGF}_{2 \alpha}$ release and prevented abortion in 5 of 6 gilts. Two of these litters had no LPS-related fetal death, one had extensive fetal death and two could not be evaluated. The question of survival of the litter is crucial to the practical significance of treatment of endotoxemic pregnant sows in the field. The study reveals that inhibition of LPS-generated PGF $_{2 \alpha}$ synthesis cannot preserve pregnancy in the pig in all cases. Other mechanisms, possibly vasotoxic, might cause fetal death.

Based on the results of this experiment it was concluded that:

1) LPS induced abortions in early pregnant pigs due to $\mathrm{PGF}_{2 \alpha}$ synthesis and its luteolytic effect. The abortifacient effect corresponded well to that of CP and the effects of both corresponded to those observed in later stages of gestation;

2) FM-treatment did not block the temperature rise associated with endotoxemia suggesting FM had little, or no, antipyretic capacity;

3) FM dramatically decreased the base blood levels of 15-ketodihydro-PGF ${ }_{2 a}$ and preven- 
ted abortion in gilts by inhibition of massive prostaglandin biosynthesis induced by endotoxin;

4) A satisfactory answer as to whether LPS maintained fetopathic effect in FM-treated gilts was not obtained, but, LPS-related fetal death was observed in at least 1 case. Further investigation on relation between endotoxins and prostaglandin syntheis inhibition is desirable for the purpose of utilization of the flunixin meglumine in protection of pregnant swine against loss of pregnancy due to infectious diseases.

\section{Acknowledgements}

The authors are thankful to Ms Catharina Falkenberg and Ms Christina Plöen for technical assistance, Prof. Lars-Erik Edqvist at the Dept. of Clinical Chemistry for placing the departments facilities to our disposal and Prof. G. H. Stabenfeldt of Davis, California for language review and valuable discussions. Supported by a grant from the Swedish Council for Forestry and Agricultural Research.

\section{References}

Bazer FW, First NL: Pregnancy and parturition. J. Anim. Sci. 1983, 57, suppl. 2, 425-460.

Bosu WTK, Edqvist L-E, Martinsson K, Johansson $E D B$ : The effect of various dosages of lynesterol on the plasma levels of oestrogens and progesterone during the menstrual cycle in the rhesus monkey. Contraception 1976, 13, 677-684.

Bottoms GD, Fessler JF, Roesel DF, Moore AB, Frauenfelder $H C$ : Endotoxin-induced hemodynamic changes in ponies: Effects of flunixin meglumine. Amer. vet. Res. 1981, 42, 1514-1518.

Burrows GE: Therapeutic effect of phenylbutazone on experimental acute Escherichia coli endotoxemia in ponies. Amer. J. vet. Res. 1981, 142, 94 99.

Cort N: A clinical study on the ef fect of a Gramnegative bacterial endotoxin and cloprostenol in nonpregnant and 60 days pregnant gilts. Anim. Reprod. Sci. 1986, 10, 133-145.

Cort $N$, Kindahl: The effect of a bacterial endotoxin or cloprostenol on the clinical status and hormo- nal levels in 80-100 days pregnant gilts. Acta vet. scand. 1986, 27, 145-158.

Cort N, Kindahl H, Einarsson S: The effect of a Gramnegative bacterial endotoxin and cloprostenol on the plasma levels of 15-keto-13, 14-dihydro- $\mathrm{PGF}_{2 a}$ progesterone, oestradiol-17 $\beta$, oestrone sulphate and luteinizing hormone in non-pregnant and 60 days pregnant gilts. Anim. Reprod. Sci. 1986, 10, 147-162.

Culbertson Jr R, Osburn BI: The biologic effects of bacterial endotoxin: A short review. Vet. Sci. Commun. 1980, 4, 3-13.

Dennis SM: The effect of bacterial endotoxin on pregnancy. Vet. Bulletin 166, 36, 123-128.

First NL, Bosc MJ: Proposed mechanisms controlling parturition and the induction of parturition in swine. J. Anim. Sci. 1979, 48, 1407-1421.

Fletcher JR, Herman CR, Remwell PW: Improved survival in endotoxemia with aspirin and indomethacin pretreatment. Surg Forum, 1976, 27, 11-12.

Flower RJ: Drugs which inhibit prostaglandin biosynthesis. Pharmacological Reviews 1974, 26, 33-67.

Guthrie HD, Polge C: Treatment of pregnant gilts with a prostaglandin analogue, cloprostenol, to control oestrus and fertility. J. Reprod. Fert. 1978, 52, 271-273.

Hardie EM, Rawlings $C A$, Shotts EB, Waltman $D W$, Rakich PM: Escherichia coli-induced lung and liver dysfunction in dogs: Effects of flunixin meglumine treatment. Amer. J. vet. Res. 1987, 48, 56-62.

Harper MJK, Skarnes RC: Inhibition of abortion and fetal death produced by endotoxin or prostaglandin $\mathrm{F}_{2 a}$. Prostaglandins 1972, 2, 295-308.

Houdeshell GD, Hennessey PW: A new nonsteroidal, antiinflammatory analgesic for horses. J. Equine Med. surg. 1977, 1, 57-63.

Kindahl H, Edqvist L-E, Granström E, Bane A: The release of prostaglandin $F_{2 \alpha}$ as reflected by 15 -keto-13, 14-dihydroprostaglandin $F_{2 a}$ in the peripheral circulation during normal luteolysis in heifers. Prostaglandins 1976, 11, 871-878.

Linderg $A A$, Sheldon $G E$, Svensson $S B$ : Induction of endotoxin tolerance with nonpyrogenic 0 -antigenic oligosaccharide-protein conjugates. Infect. Immun. 1983, 41, 888-895. 
Moore JN, Hardee MM, Hardee GE: Modulation of arachidonic acid metabolism in endotoxic horses: Comparison of flunixin meglumine, phenylbutazone and a selective thromboxane synthetase inhibitor. Amer. J. vet. Res. 1986, 47, 110-113.

Odensvik $K$, Cort N, Basu S, Kindahl $H$ : Effect of flunixin meglumine on prostaglandin $\mathrm{F}_{2 a}$ synthesis and metabolism in the pig. J. vet. Pharmacol. Therap. 1989, 12, (in press).

Podaný J, Vanicek J, Stejskal J, Selének L: Induction of abortion with prostaglandin $F_{2 a}$ in gilts and their subsequent fertility. Theriogenology 1982, 17, 393-400.

Rieder RF, Thomas L: Studies on the mechanisms involved in the production of abortion by endotoxin. J. Immunol. 1960, 84, 189-193.

Roberts JS, Barcikowski B, Wilson L, Skarnes RC, $M c C r a c k e n ~ J A$ : Hormonal and related factors affecting the release of prostaglandin $F_{2 a}$ from the uterus. J. Ster. Biochem. 1975, 6, 1092-1097.

Robertson HA, King CJ: Plasma concentrations of progesterone, oestrone, oestradiol-17 $\beta$ and of oestrone sulphate in the pig at implantation, during pregnancy and at parturition. J. Reprod. Fert. 1974, 40, 133-141.

Rodriguez-Martinez $H$, Kunavongkrit $A$ : Chronic venous catheterization for frequent blood sampling in unrestrained pigs. Acta vet. scand. 1983, 24, 318-320.

Skarnes RC, Brown SK, Huss SS, McCraken JA: Role of prostaglandin $\mathrm{E}$ in the biphasic fever response to endotoxin. J. exp. Med. 1981, 154, 1212-1224.

Svensson $S B$, Lindberg $A A$ : Immunochemistry of Salmonella 0-antigens: Preparations of an octasaccharide-bovine serum albumin immunogen representative of Salmonella serogroup B 0-antigen and characterization of the antibody response. J. Immunol. 1978, 120, 1750-1757.

Turek JJ, Templeton B, Bottoms GD, Fessler JF: Flunixin meglumine attenuation of endotoxin-induced damage to the cardiopulmonary vascular endothelium of the pony. Amer. J. vet. Res. 1985, 46, 591-596.

Vernimb GD, Hennessey $P W$ : Clinical studies on flunixin meglumine in the treatment of equine colic. J. Equine Med. Surg. 1977, 1, 111-116.
Wang JT, Dunne HW, Griel LC, Hokanson JF, Murphy DM: Mortality, antibody development and viral persistence in porcine fetuses incubated in utero with SMEDI (Entero-) virus. Amer. J. vet. Res. 1973, 34, 785-788.

Wrathall $A E$, Wray $C$, Bailey J, Wells $D E$ : Experimentally induced bacterial endotoxaemia and abortion in pigs. Brit. vet. J. 1978, 134, 225-230.

Wrathall $A E$ : Mechanisms of porcine reproductive failure. Vet. Annual 1980, 20, 265-274.

Wright K, Collins DC, Musey PI, Preedy JRK: A specific radioimmunoassay for estrone sulphate in plasma and urine without hydrolysis. J. clin. Endocr. Metab. 1978, 47, 1092-1098.

\section{Sammanfattning}

Endotoxin-inducerad abort hos tidigt draktiga gyltor och hur den kan forebyggas med flunixin meglumin.

Mălsăttningen med denna studie var att undersőka effekten av endotoxin pá tidigt drăktiga gyltor och flunixin meglumins (FM) formåga att motverka endotoxinets abortframkallande egenskaper. Flunixin ăr en hămmare av enzymet cyclooxygenas, som syntetiserar prostaglandiner och nărstående fơreningar. Tio gyltor som var $\mathbf{3} 30$ dagars drăktighet anvăndes $\mathrm{i}$ detta försők. Ȧtta djur injicerades med endotoxin (lipopolysackarid, LPS) frán Salmonella typhimurium och 2 djur behandlades med $500 \mu$ g cloprostenol (CP). Sex av de LPS-behandlade djuren erholl en total dos av flunixin om $4 \mathrm{mg} / \mathbf{k g}$ kroppsvikt via 2 olika behandlingsstrategier. Kliniska fơrändringar observerades och plasmanivåer av 15-keto-13, 14-dihydroprostaglandin (PG) $\mathrm{PGF}_{2 a}$, progesteron och ostronsulfat (ES) bestămdes med radioimmunologisk metodik.

LPS framkallade typiska tecken på endotoxinemi och en monofasisk feber hos alla LPS-behandlade djur. Ingen febernedsăttande effekt av FM observerades. Djuren som behandlades med CP eller enbart LPS aborterade inom 34 tim. Av de 6 djuren som kombinationsbehandlades med LPS och FM, aborterade ett djur inom 34 tim, medan 5 vidmaktholl drăktigheten. Dessa fem djur aborterades en vecka senare med CP för att mőjliggöra en makroskopisk undersőkning av fostren. Två kullar forlorades pga att modern át upp dem, 2 aborterades utan tecken på 
fosterskador och 1 kull uppvisade tydlig fosterdöd tydande pả att endotoxinet hade haft negativ inverkan.

Blodplasmanivåerna av prostaglandinmetaboliten ökade 10-faldigt omedelbart efter LPS-injektionerna hos de 2 djur som erhöll enbart LPS och progesteron sjönk snabbt. I samband med aborterna syntes vidare end 5-10 faldig ökning i plasmanivảerna av prostaglandinmetaboliten. $\mathrm{CP}$ medförde inte nágon omedelbar fơrăndring i prostaglandinmetabolitnivåerna, men ett liknande svar syntes i samband med aborten som hos de LPS-inducerade djuren. I den FM-behandlade gruppen syntes endast en smärre ökning i prostaglandinmetaboliten och progesteronniváerna uppvisade en övergáende sänkning. Östronsulfat, som normalt ligger högt vid 30 dagars dräktighet, sjönk snabbt inom $\mathbf{4 8}$ tim hos gyltor som aborterade till skillnad mot icke-aborterade djur som uppvisade en långsam sänkning av ES under loppet av 3-5 dagar.

Detta resultat tyder på att FM hämmar den LPS-inducerade prostaglandinsyntesen och således förhindras luteolys och abort hos tidigt dräktiga gyltor.

(Received October 3, 1989; accepted October 25, 1989).

Reprints may be requested from: Nicholas Cort, Laboratory of Pathology, National Veterinary Institute, P. O. Box 7073, S-750 07 Uppsala, Sweden. 